Исидора Церовац Ђорић

Универзитет у Београду

Филолошки факултет

isidoracerovac@live.com
УДК 821.161.1.09:314.743(=161.1)(497.1)

https://doi.org/10.18485/slavistika.2020.24.1.24

Информативни прилог примљено 21.03.2020.

прихваћено за штампу 21.05.2020.

\title{
ДВА ПИСМА С. В. ШТЕЈНА У АРХИВУ ЈУГОСЛАВИЈЕ
}

Радећи над архивском грађом, која се, укратко, тиче руске емиграције у Југославији и међусобних односа са краљем Александром Карађорђевићем, упознали смо се са бројним писмима, која су нам донела нова сазнања. У овом раду издвајамо два писма Сергеја Владимировича Штејна упућена краљу Александру Карађорђевићу. Штејн, иако мање познат руски писац и песник, оставио је дубок траг у славистици уопште, као и у руској емиграцији. Прво писмо С. В. Штејн је написао поводом десетогодишњице од ступања на престо Краља Александра Карађорђевића, 1931. године, уз песму на српском језику. Друго писмо, пронађено међу архивском грађом датира из 1928. године. Путем описа садржине ових малих историјских споменика у раду откривамо нове детаље у вези са биографијом Штејна и односима краља са представницима руске емигације.

Кључне речи: краљ Александар Карађорђевић, руска емиграција, епистоларна грађа, С. В. Штејн.

Working on archival materials which concern the Russian emigration in Yugoslavia and its relations with King Alexander Karađorđević we got acquainted with numerous letters in which much new information was discovered. In this paper we highlight two letters by Sergey Vladmirovich Stein addressed to King Alexander. Even though Stein was not a famous Russian writer and poet, nonetheless he left a deep mark in Slavic studies in general and as a prominent member of the Russian emigration. S. V. Stein wrote the first letter and a poem to King Alexander on the occasion of the tenth anniversary of his reign in 1931. The second letter found among archival material was written in 1928. In this paper we reveal new details from Stein's biography and the king's relations with representatives of the Russian emigration trough the content of these so-called minor historical monuments.

Keywords: King Alexander Karađorđević, Russian emigration, epistolary materials, S. V. Stein.

Вечна успомена на нашег драгог професора Бобана Ћурића, који наставља да нас инспирише.

Овај рад представља један мали део вишегодишњег истраживачког циклуса о руској емиграцији у Југославији, и то првенствено на основу архивске грађе, која се односи на везе између краља Александра Карађорђевића и руских емиграната. Будући да је наведена грађа велика по обиму и садржају, за потребе овог рада смо се, пре свега, фокусирали само на писмо С. В. Штејна као илустрацију како један, макар и мали архивски податак може да употпуни биографске податке и да открије детаље из живота писца, али и истовремено надогради информацију о односима краља са руском емиграцијом.

Сергеј Владимирович Штејн је рођен 3. маја 1882. године у Павловску, као прво од четворо деце (Наталија и близнакиње Софија и Елена). Сведок 
на његовом крштењу, односно кум, био је генрал-потпуковник Исидор Францевич Штејн. Како наводи А. Арсењев немачка племићка породица von Stein je у XII веку дошла из кнежевине Насау прво у Пољску, где се прадеда Јан фон Штејн венчао са кнегињом из фамилије Корсини (Арсењјев 2011). Детињство је провео у Харкову, у кући стрица, чувеног лингвисте и професора Александра Афанасјевича Потебње. Завршио је археолошки институт у Санкт Петербургу и правни факултет Казанског универзитета. Штејн се женио три пута, а прва жена му је била Ина Андрејевна Горенко, иначе старија сестра Ане Ахматове са којом је Сергеј дуго био пријатељ. Интересантно је да је његова сестра Наталија Владимировна Штејн у првом браку била удата за песника „Сребреног века“, једног од оснивача акмеизма, Валентина Инокентијевича Аненског, а Сергеј Штејн је био рецензент његових ранијих радова. Чланци и преводи Сергеја Штејна су излазили у издањима Новое время, Литературный вестник, Славянские известия, Исторический Вестник, Живописное обозрение, Русский библиофил, Лукоморье, а био је и редактор у часопису Слово, у којем су објављивани и радови Ане Ахматове, Николаја Гумиљова, Александра Блока и Валерија Брјусова (Оболевич 2019: 85). Објавио је 1908. год. антологију „Словенски песници. Преводи и карактеристике“, а Николај Гумиљов био један од првих који је написао позитивне критике на овај рад.

Штејн је на Тартуском универзитету, у Естонији, од 1920. до 1928. год. држао предавања, између осталог, и о српско-хрватској књижевности (Ponomarjova, Šor 2001). Естонију је морао да напусти из три главна разлога. Прво због тога што није био поново изабран на место професора словенске филологије, друго због неуспеле одбране докторске дисертације на тему Пушкина, у јуну 1928. године, а треће због банкрота новина Последние известия, на чијем челу је био управо Штејн. Након неуспеха у Естонији преселио се у Љипају у Летонији 1928. год., где је радио као професор руског језика у Љипајској руској гимназији. Познато је да се Штејн преселио у Београд 1931. године, а већ 1933. год. прелази у Далмацију у Дубровник, где се прекрштава у католичку веру (Арсењјев 2011). Од 1935. године био је именован за професора на Вишој филозофској и теолошкој школи при Доминиканском реду у Дубровнику, гдје предаје нове предмете: историју руске религиозне филозофије и руски језик (Slukan-Marković 2001). Последње године живота провео је у Западној Немачкој и умро је у Минхену 1955. г.

Истражујући архивску грађу, пронашли смо два писма С. Штејна упућена Краљу Александру. Једно је послато поводом десетогодишњице од ступања на престо Краља Александра Карађорђевића 1931. године (АЈ ф:74 ; ф:19) заједно са песмом на српском језику. Друго писмо (АJ ф:74 ; ф:20), за које сматрамо да је важно поменути га у овом раду датира из 1928. године.

У првом писму (АЈ ф:74 ; ф:20) из 1928. године, када се Штејн преселио у Летонију, пише краљу како је „нашао смелости“ да му се обрати због велике пажње коју његово величанство поклања руским културним радницима, избеглим из бољшевичке Русије. Подсећајући краља у писму на свој рад, он му напомиње да је 1908. године у „Петрограду“ издао књигу превода и књижевних описа под општим насловом „Словенски Песници“1. Даље захваљујући овом

\footnotetext{
${ }^{1}$ Штейн С. Славянские поэты: Переводы и характеристики. СПб., 1908.
} 
писму сазнали да су у наведену антологију, која је иначе написана на основу Штејновог истраживачког рада на Балкану, ушле компилације песама Краља Николе Црногорског, Јована Јовановића Змаја, Јована и Војсилава Илића, Јована Дучића и других. Управо је захваљујући тој књизи Штејн стекао славу међу писцима, а за овај књижевни подухват Штејн напомиње у овом писму да га је црногорски краљ Никола I одликовао орденом кнеза Данила. Свакако једно од најинтересантнијих сазнања је то да се писац упознао са краљем Александром 31. марта 1908. године у Зимском Дворцу у Санкт Петербургу.

Даље сазнајемо да је Штејн 12 година био стални сарадник часописа Славянские известия, које је издавало Петроградско Словенско добротворно друштво. Он наводи да је уз његово учешће, управо то друштво формирало научнокњижевни одсек „Славенской беседы“. Истовремено био је и секретар Управе Државног Руског Дунавског Паробродарства, које је, како Штејн пише, за циљ имало да учврсти везе између Русије и словенских држава. Штејн на крају писма моли краља Александра да због незадовољства које осећа у Летонији, а на основу његових радова у корист словенско-руских односа пређе у Србију и добије стипендију, како би радио у педагошкој и књижевној струци. У том тренутку је Штејн радио као професор у гимназији у Љипаји, где је ушао у конфликт са директором школе, па можемо претпоставити да је то један од разлога његовог незадовољства. Наведено писмо краљу представља својеврсни вапај Штејна, чему у прилог иде крај писма у којем моли да му се „бар кратко“ одговори на његову молбу.

Друго писмо (AJ ф:74; ф:19) написано краљу Александру поводом десетогодишњице његове владавине 1931. године, такође прожимају сетан и незадовољвајући тон. На почетку писма Штејн поново подсећа краља на своја најзначјанија дела, као и у првом писму. Он у први план ставља његову антологију „Словенских песника“, уз допуну да га је за то дело 1909. године српски краљ Петар I одликовао орденом Светог Саве. Штејн у писму даље наводи да је након 1928. године, када је објављен његов рад о „Пушкину и Хофману“, један примерак послао краљу, као и књигу „Пушкин-мистик“, а све у знак захвалности и уважавања, као „руски патриота“, за многобројна добра дела којима је краљ ,засипао“ његове земљаке, који су остали без Отаџбине. Из писма такође сазнајемо да је Штејн био и научни секретар Српског одељења за оријенталистику.

Даље у писму, Штејн говори позитивно о државном уређењу „срећне“ Југославије истичући заслуге краља у томе, и наглашава да жели да остане у њој, јер му између осталог одговара и због политичких уверења. Пише да је почео свој „последњи пут служења Његовој (краљевој) отаџбини“ тако што је у 55-ој години живота постао студент Православног Богословског Факултета Универзитета у Београду, са намером да се посвети духовно-религиозном раду у Југославији, што је такође нов и битан податак. Због тога је замолио краља две ствари, прво да њега и његову жену прими као „верне поданике Његовог Краљевског Величанства“, и друго да му одобри за време студија стипендију, са којом би он и његова жена могли да наставе скромно да живе у Југославији.

Штејн пред крај писма пише да ће за све што краљ учини за њега да му буде најискреније захвалан „све до гроба“", и да ће посветити сва своја знања, искуство и перо на верно служење њему и Словенима његове отаџбине. Врхунац 
свог поштовања и уважавања краља Штејн изражава на крају писма, где наводи да поводом десетогодишњице ступања на краљевски престо, а у знак захвалности, поклања његовом величанству „од искреног руског срца“ песму написану на српском језику. На нашу жалост песма није сачувана уз писмо.

\section{Цитирана литература}

Арсеньев, А. Б. „Русская эмиграция в Дубровнике“. Европа. Международный альманах 10, 2011: 132-133.

[Arsenjev, A. B. „Russkaya emigracia v Dubrovnike“. Evropa. Mezdunarodnyi al'manah 10, 2011: 132-133]

Валиев, М. Т. «История семьи Штейн - мифы и действительность». [В:] В.В. Бибиков и др. (ред.) Генеалогический вестник 53. Санкт-Петербург, 2016, 90110.

[Valiev, M. T. «Istoriâ sem'i Štejn - mify i dejstvitel'nost'». [V:] V.V. Bibikov i dr. (red.) Genealogičeskij vestnik 53. Sankt-Peterburg, 2016, 90-110]

Оболевич, Т. «Сергей Штейн о В.С. Соловьеве». Соловьевские исследования 2 (62), 2019: 83-95.

[Obolevič, T. «Sergej Štejn o V.S. Solov'eve». Solov'evskie issledovaniâ 2 (62), 2019: 83-95]

Ponomarjova, Galina, Šor Tatjana. „Sergej Štejn kao predavač Tartuskoga sveučilišta“ / S ruskoga, iz rukopisa, prevela Irena Lukšić. Književna smotra : časopis za svjetsku književnost 33, 1=119, 2001: 51-56.

Slukan-Marković, Sanja (prir.) „Radovi ruskih emigranata tiskani u Hrvatskoj : Irina Aleksander-Kunjina, Valentin Ivanovič Gorjanski, Jurij Erastovič Ozarovski, Vladimir Rozov, Sergije Vladimirovič Štejn“. Književna smotra : časopis za svjetsku književnost 33, 1=119, 2001: 119-124.

\section{Извори}

АЈ - Архив Југославије. ф:74, ф:20

[AJ- Arhiv Jugoslavije. f:74, f:20]

АЈ - Архив Југославије. ф:74, ф:19

[AJ- Arhiv Jugoslavije. f:74, f:19] 
Исидора Церовац Джорич

\title{
ДВА ПИСЬМА С. В. ШТЕЙНА В АРХИВЕ ЮГОСЛАВИИ
}

\begin{abstract}
Резюме
Статья является частью исследовательского процесса и работы над архивными материалами в рамках докторской диссертации на тему переписки русских эмигрантов с королем Александром Карагеоргиевичем. В данной работе приводятся письма Сергея Владимировича Штейна, которые помогают нам в установлении некоторых деталей биографии этого ученого, переводчика и поэта.

Ключевые слова: король Александр Карагеоргиевич, русская эмиграция, десятилетие правления, архивные материалы.
\end{abstract}

